\title{
Making visible the people who feed us: Educating for critical food literacy through multicultural texts
}

\author{
Lina Yamashita ${ }^{a *}$ \\ University of California, Davis \\ Diana Robinson ${ }^{\mathrm{b}}$ \\ Food Chain Workers Alliance
}

Submitted September 22, 2015 / Revised November 18 and December 7, 2015 /

Accepted December 9, 2015 / Published online February 10, 2016

Citation: Yamashita, L., \& Robinson, D. (2016). Making visible the people who feed us: Educating

for critical food literacy through multicultural texts. Journal of Agriculture, Food Systems, and Community

Development, 6(2), 269-281. http://dx.doi.org/10.5304/jafscd.2016.062.011

Copyright (C) 2016 by New Leaf Associates, Inc.

\begin{abstract}
The number of food systems education programs and curricula in the U.S. has increased in response to the growing interest in where food comes from and how it is grown. While these educational efforts aim to increase learners' connection to food and the land, they do not always focus explicitly on the structural inequities that shape food systems and the experiences of food workers. There is, however, a small but growing number of food

a * Corresponding author: Lina Yamashita, School of Education, University of California, Davis; 1 Shields Avenue; Davis, California 95616 USA; lyamashita@ucdavis.edu

b Diana Robinson, Food Chain Workers Alliance; 1730 West Olympic Boulevard \#300 Room K; Los Angeles, California 90015 USA; diana@,foodchainworkers.org

\section{Disclosure}

Diana Robinson is the campaign and education coordinator of the Food Chain Workers Alliance (FCWA). In this paper, the authors use a comic book produced by FCWA as an illustrative example of how multicultural texts can potentially foster critical food literacy.
\end{abstract}

systems education programs that seek to shed light on and challenge these inequities. We build on these existing critical approaches to food systems education by introducing the notion of critical food literacy — or the ability to examine one's assumptions, grapple with multiple perspectives and values that underlie the food system, understand the larger sociopolitical contexts that shape the food system, and take action toward creating just, sustainable food systems. In particular, we discuss and highlight the potential of multicultural texts to make visible food workers, especially those who tend to be less visible, and identify pedagogical strategies for cultivating critical food literacy by drawing on empirical research on response to multicultural literature and using a multicultural text produced by the Food Chain Workers Alliance as an illustrative example. Ultimately, we argue that citizens who develop and demonstrate critical food literacy can participate in public, democratic discourse about food systems and help create food systems that are just and sustainable for all. 


\section{Keywords}

critical food literacy; food systems education; food labor; pedagogy; values

\section{Introduction}

There is now increasing interest in healthy food and sustainable agriculture, as indicated by the demand for locally grown, organic food, and the rise of farmers markets and community supported agriculture (Gray, 2013). This has been driven, in part, by consumers' curiosity and concerns about where food comes from, how animals are treated, and the environmental impact of food production. In contrast to the burgeoning interest in small-scale or environmentally friendly alternatives, however, less attention has been paid to issues of labor in food systems (Gray, 2013). Food systems that are truly sustainable feature not only practices that reduce environmental impact but also working conditions and employment practices that protect the workers' human rights (Jayaraman, 2013). The question that rises is: How can the general public develop a critical awareness of the people who grow, process, distribute, sell, and serve food and of the sources of agency and oppression among these food workers?

Attention has begun to be paid in recent years to the people behind food. ${ }^{1}$ Constituting one-sixth of the workforce in the U.S. (Food Chain Workers Alliance, 2012a), food workers contribute over US $\$ 2.2$ trillion in goods and services annually. ${ }^{2}$ In 2009, the Food Chain Workers Alliance (FCWA) was formed as nine organizations, including unions and worker centers, came together to discuss the importance of organizing an alliance to represent their collective interest and work toward a fair and just food system for all. The FCWA, where author Robinson works as the campaign and education coordinator, currently is made up of 25 organizations that collectively represent close to 300,000 workers in the food system. It serves as a platform to uplift food worker campaigns and educate the general public about food worker issues.

\footnotetext{
1 These people include those who work in food production, processing, distribution, retail, and service.

${ }^{2}$ We calculated this amount by using the 2012 U.S. Economic Census for total sales for NAICS codes 311, 722, and 445
}

Educational institutions can also play an important role in making visible the experiences of food workers, particularly those who tend to be less visible. We argue that the use of multicultural texts (texts that reflect diverse experiences of previously underrepresented or omitted groups) that humanize food workers and highlight their experiences can encourage learners of all ages to think critically and examine their assumptions about food systems and the people behind food. We further assert that the time is now ripe for using such texts (e.g., news articles, comics, books, films, talk shows, TED talks), particularly given their recent proliferation in the media.

To lend support to this argument, we begin by asserting that while existing food systems education programs, such as school gardens, farm-toschool programs, and student farms on university campuses, typically aim to increase students' connection to food and the land, they do not necessarily encourage students to explicitly consider the structural inequities that shape food systems and the experiences of food workers. Important exceptions exist, however, and the purpose of this commentary is to build on examples of critical approaches to food systems education by introducing the notion of critical food literacy. Drawing on previous literature on critical literacy, we define critical food literacy as the ability to examine one's assumptions and grapple with multiple perspectives that underlie food systems, understand the larger sociopolitical contexts that shape food systems, and take action toward just, sustainable food systems. We also draw on studies from literacy education on students' responses to multicultural texts with social justice themes and use a multicultural text produced by the FCWA to identify and illustrate pedagogical strategies that can help foster critical food literacy. We end the paper by calling for additional empirical research on critical food literacy and discussing its importance in efforts to build just, sustainable food systems.

(available at http:/ / factfinder.census.gov/) and the 2012 USDA Census of Agriculture report (available at http://www.agcensus.usda.gov/Publications/2012/Full Repo rt/Volume 1, Chapter 1 US/st99 1001 001.pdf). 
The Need for Critical Approaches to

Food Systems Education

Interest in food systems education for youth and young adults has grown, as evidenced by the proliferation of school gardens (Williams \& Dixon, 2013), farm-to-school programs (Feenstra \& Ohmart, 2012), undergraduate majors and fieldbased learning opportunities that focus on food systems (Hilimire, Gillon, McLaughlin, DowdUribe, \& Monsen, 2014; Jordan et al., 2014), and student farms at university campuses (Parr \& Trexler, 2011; Sayre \& Clark, 2011). The growth of these types of food systems education programs can be explained, in part, by the rising interest in improving health, preventing obesity, teaching methods for growing and preparing healthy food, and eating locally grown, organic foods (Flowers \& Swan, 2012; Guthman, 2008; Williams \& Dixon, 2013). In addition, farm-to-school programs and sustainable food projects on university campuses are often justified in terms of connecting with local farmers and supporting local agriculture (Bagdonis, Hinrichs, \& Schafft, 2009; Barlett, 2011).

Although these types of food systems education programs can differ in terms of their specific goals, they all typically embrace and emphasize the value of experiential learning (Blair, 2009; Hilimire et al., 2014; Parr \& Trexler, 2011), or the notion that people learn and construct knowledge by making meaning out of their experiences (Dewey, 1938; Kolb, 2014). In the context of food systems education, experiential learning opportunities include direct exposure-whether through field trips or internships - to the processes of food production and to other locations in the food system. While experiential learning has become a popular pedagogical principle in food systems education programs, a learning-by-doing approach by itself does not necessarily guarantee the development of critical thinking about food systems, especially if it unquestioningly touts certain food practices as being sustainable.

Eating locally grown foods is an example of such a food practice commonly promoted by farmto-school programs (Allen \& Guthman, 2006) and school gardens, such as the well known Edible Schoolyard in Berkeley (Pudup, 2008). In fact, one of the principles of "edible education," as articulated by Alice Waters, the founder of the Edible Schoolyard, is that schools support farms, and local farms in particular (Gayeton, 2014). Furthermore, a 2008 report by the then Chez Panisse Foundation entitled Principles of an Edible Education: A Vision for School Lunch argued that schools should "only serve food that is seasonal, local, and delicious" (Chez Panisse Foundation, 2008, p. 14). What is problematic, however, is not so much the act of eating locally grown foods as the underlying assumption that locally grown foods are inherently ethical and sustainable, thereby overlooking structural injustices, including labor inequities, that can shape small-scale, local farms (Gray, 2013).

Not surprisingly, the value of eating locally grown foods is also emphasized on student farms on university campuses, as they are sites of local food production by the students. While students learn important practical skills for growing food and are often able to direct their own learning experiences, many students are also motivated by their desire to grow and access "good food" (Parr \& Trexler, 2011). This suggests that students who work on student farms have prior ideas about what constitutes good (and bad) food; that is, that "good food" is seasonal and locally grown. When students focus primarily on gaining knowledge and skills that align with their values of growing and accessing good food, however, they may not seek exposure to different perspectives that conflict with their values. This is problematic because students may then miss the opportunity to consider how, as scholars have described (e.g., Freedman, 2011; Johnston \& Baumann, 2010; Paddock, 2015), racial and class inequities limit access to good food or how policies and institutions created the "good" and "bad" food distinction in the first place. Without such an opportunity for critical reflection, students may develop the overgeneralized belief that eating locally grown foods automatically constitutes a "sustainable" behavior.

Such a belief, in turn, may translate to a zealous desire to teach the "right" ways to farm, cook, or eat healthy (Caldwell, 2014). In "spreading the gospel" of "good food" to others (Guthman, 2008) in a top-down manner, such teaching efforts can reinforce and perpetuate inequities and power 
differences and ignore or discount the different kinds of knowledge and skills that those being educated possess. Moreover, by instilling the values of "good food," these food systems education programs can reinforce notions of what kinds of food-related knowledge, skills, and behaviors are good or right (and therefore, which are bad or wrong), as well as who is considered knowledgeable versus ignorant (Coveney, Begley, \& Gallegos, 2012; Flowers \& Swan, 2011; Swan \& Flowers, 2015). Such notions, in turn, can privilege particular types of knowledge, such as knowledge of food production, over other types, such as knowledge of consumption (Goodman \& DuPuis, 2002) and shape what kind of knowledge is presented as undisputable, when in actuality that knowledge is messier and more contested than it is presented to be (Flowers \& Swan, 2011). These kinds of pernicious consequences can therefore potentially follow from food systems education programs that promote particular foods as being "good."

It is important to note, however, that there is now a growing number of alternative food systems education endeavors that aim to question and/or disrupt structural inequities that underlie food systems (Flowers \& Swan, 2012; Meek \& Tarlau, 2015). Examples include programs developed by the Landless Workers Movement in Brazil that encourage youth to remain in the countryside and integrate them into a collective struggle toward land reform and building just, sustainable food systems (Meek \& Tarlau, 2015). Other examples of critical approaches include Growing Power, an urban farm and nonprofit center based in Milwaukee, Wisconsin, that trains underserved youth (Walter, 2012); an undergraduate course on soul food that examined how communities of color exercise agency while also experiencing racism (Burdick, 2014); and School Grown, a gardenbased program in Toronto that employs high school students who face systemic barriers to employment (Wever, 2015). Critical approaches to food systems education therefore occur in many forms (whether job training, coursework, or social movements) and contexts (in or outside of educational institutions), with a variety of outcomes (whether growing and selling food, gaining access to land, and/or increasing understanding of oppression in the food system). The purpose of our commentary, then, is to build on these existing critical approaches to food systems education by describing one such approach that explicitly focuses on the use of multicultural texts with the aim of fostering critical food literacy, a notion that we elaborate upon below.

\section{What Is Critical Food Literacy?}

Before elaborating upon the idea of critical food literacy, we discuss two related concepts: food literacy and critical literacy. Food literacy as a concept has gained popularity over the last decade (Sumner, 2013) and has often been used to justify the development of food systems education programs. While many definitions exist, it typically refers to the ability of individuals to understand the origins and production of food, apply nutritional knowledge to food choices, and to grow and prepare food (Cullen, Hatch, Martin, Higgins, \& Sheppard, 2015; Goldstein, 2014; Vidgen \& Gallegos, 2014). Food literacy defined in this way, however, shifts the responsibility of solving problems in the food system away from public policies toward individuals by focusing on increasing knowledge and skills (Kimura, 2011).

Some existing definitions of food literacy go beyond this consumer-oriented approach and include the ability to understand social, environmental, economic, political, and cultural aspects of the food system and make healthy decisions that help build a sustainable food system (Cullen et al., 2015; Goldstein, 2014; Sumner, 2013; Wever, 2015). Furthermore, in her framework for critical food pedagogy Wever (2015) also includes what she calls critical or emancipatory knowledge and skills, including the ability to engage in critical reflection, demonstrate "critical knowledge of the social and economic forces of a society that affect food" (p. 49), and "exercis[e] food-related behaviors that support a democratic, socially, economically, and ecologically just food system" (p. 49).

Educators and scholars have justified the importance of these more critical and socially and politically grounded conceptions of food literacy by emphasizing the need to disrupt the industrial food system and create alternative food systems that are more sustainable (e.g., Goldstein, 2014; Wever, 
2015). However, in such conceptions of food literacy, the object of critical reflection-a process that involves unveiling hidden power structures and understanding multiple perspectives - is limited to the industrial food system and not extended to alternative food systems (Holloway, Kneafsey, Venn, Cox, Dowler, \& Tuomainen, 2007). By depicting alternative food systems as inherently more sustainable, despite the limited evidence base of positive impacts (Forssell \& Lankoski, 2015), the existing notions of food literacy reinforce the "conventional-alternative" dualism (Holloway et al., 2007) and reflect oversimplified views about which food systems (and therefore what types of food-related behaviors) are sustainable and unsustainable.

Toward promoting more nuanced conceptions of food systems and extending the process of critical reflection to all types of food systems - not just the industrial food system-we introduce the notion of critical food literacy, which is rooted in the idea of critical literacy. Theorized by scholars including Paulo Freire and Ira Shor, critical literacy has four dimensions, as described by Lewison, Flint, and Van Sluys (2002). These include the ability to (1) disrupt the commonplace (i.e., challenge one's conceptions, beliefs, or internalizations of common stereotypes or ideologies); (2) interrogate multiple viewpoints; (3) focus on larger sociopolitical issues; and (4) use language to take action toward promoting social justice, exercising power, and questioning practices of privilege and injustice. Others have written about critical literacy as the ability to use words to challenge the status quo and read the world or transform social relations, material conditions, and the world more broadly (e.g., Freire, 1985; Lewis, Pyscher, \& Stutelberg, 2014; Luke, 2012; Shor, 1999). Critical literacy therefore is rooted in critical theory, which is based on the premise of transforming social and material conditions through questioning power relations, critiquing society, and challenging social assumptions (Bredo \& Feinberg, 1982; Geuss, 1981).

Drawing on these notions of critical literacy, we define critical food literacy as the ability to (1) examine one's own values with respect to food systems; (2) grapple with multiple values and perspectives that underlie food systems; (3) under- stand the larger sociopolitical contexts and factors that shape food systems; and (4) take action toward social justice in food systems and sustainability more broadly. While the concept of "critical food literacy" is relatively new, Winslow (2012) used it in her dissertation, arguing that fostering critical food literacy is one approach to teaching sustainability within her field of rhetoric and composition. Specifically, Winslow (2012) defined critical food literacy as the

ability to locate and critically analyze information and arguments about America's varying relationships to food and food production, the political implications and environmental impact of industrialized farming, and the current re-emergence of the small farm and local food movements as pieces of the effort to restructure and/or transform industrialized food systems into more sustainable systems. (p. 4)

While Winslow's definition and ours are both informed by the concept of critical literacy, our notion of critical food literacy is explicitly rooted in the importance of making visible the people who tend to be less visible; recognizing their experiences, knowledge, and skills; and considering and grappling with multiple perspectives and values that underlie food systems.

It is crucial to note that other scholars who have written about food systems education and sustainability education more broadly have similarly articulated the importance of encouraging students to examine their own assumptions and consider multiple or conflicting perspectives (e.g., Anderson, 2013; Burns, 2011; Galt, Parr, Van Soelen Kim, Beckett, Lickter, \& Ballard, 2013; Julier \& Gillespie, 2012; Wals \& Dillon, 2013). Furthermore, Wals and Dillon (2013) claimed that achieving a sustainable society requires people to demonstrate pluralism of thought and divergent thinking and "engage in a process of self-reflection on the relationship between their own guiding assumptions... and those of others" (p. 256). Such self-reflection, in turn, can encourage those who wish to inculcate "good" food practices to "listen, watch, and sometimes even stay away instead" 
(Guthman, 2008, p. 444) from the communities they are putatively teaching.

Despite this recognition of the importance of educating students to grapple with diverse perspectives, values, and beliefs that underlie food systems, however, there is currently little research on the types of learning experiences, pedagogical strategies, and the roles of educators that contribute to the development of critical food literacy. Toward the end of addressing this gap in the literature, we illustrate the potential of multicultural texts about or by food workers in cultivating critical food literacy. ${ }^{3}$ Below, we draw on the transactional theory of reading and on studies that have examined students' responses to multicultural literature that explore social justice issues to identify pedagogical strategies that can foster critical food literacy.

\section{Critical Food Literacy Through Multicultural Texts} Louise Rosenblatt $(1994,2003)$, literacy education scholar, described the act of reading a text as a transaction between the reader and the text that can result in a construction of meaning, through the process of drawing upon prior experiences or knowledge to make sense of the people and/or situations depicted in the text. This means that when readers reflect on the same text again later, they may construct new meanings, particularly if their "reservoir[s] of experiences" (Rosenblatt, 2003 , p. 70) have expanded or deepened. In addition, transactions with texts can help "us to understand ourselves and others, for widening our horizons to include...cultures different from our own, for helping us to clarify our conflicts in values, for illuminating our world" (Rosenblatt, 1982, p. 276).

While Rosenblatt's transactional theory of reading is often applied to literary texts, she explains that transactions with nonfictional texts can also be critical, inciting people to examine their values or beliefs. Moreover, by highlighting the experiences of people whose voices have

\footnotetext{
${ }^{3}$ It is important to note that the use of multicultural texts is merely one of many methods for potentially fostering foster critical food literacy and helping citizens make informed, nuanced decisions. Other potential approaches include
}

historically been underrepresented or silenced, multicultural texts about or by food workers can serve as what Dixon (2015) calls "counterstories" or narratives that reveal structural inequities and challenge assumptions about the people behind food and the causes of food injustice more broadly. Further building on this idea and drawing on empirical research on students' responses to multicultural literature, we discuss four pedagogical strategies below that educators can use to encourage learners to critically examine their beliefs and consider divergent values.

\section{Critical lenses and horizontal texts}

One way to encourage students to consider divergent values is to provide opportunities to read a given text using different critical lenses, with each lens illuminating or raising questions about certain aspects of a text. For example, students can use social class, race, or gender lenses to attend to whether and how the text reinforces, critiques, or challenges stereotypes based on class, race, or gender, respectively (Appleman, 2014; Beach, Thein, \& Parks, 2008; Gellis, 2002). Research has shown that reading through these lenses can give students the opportunity to notice aspects of texts students would not have noticed otherwise and encourage students to explore perspectives that they may not have subscribed to (Appleman, 2014; Beach et al., 2008).

To further facilitate learners in reading texts through critical lenses, they can also be given supportive documents that highlight particular issues or topics. Referring to these supportive documents as "horizontal readings," Sumara (1998) discussed how these supplemental texts can help shed light on the larger social, historical, and political factors that shape the experiences of characters in the texts and can encourage learners to consider which values are represented, privileged, or ignored. As a case in point, Beach et al. (2008) found that as high school students responded to multicultural literature using critical lenses and horizontal readings,

offering internships at different locations in the food system or revising food and agricultural policies; however, a discussion of these other approaches is beyond the scope of this commentary. 
they learned to question stereotypes associated with race, class, and gender, although some had difficulty identifying institutional aspects of White privilege. Giving learners the opportunity to engage with multicultural texts about or by food workers through critical lenses and horizontal readings, then, may foster critical food literacy by inviting students to reflect on their values and beliefs regarding food systems and consider multiple perspectives.

\section{Reflective writing}

Reflective writing can complement and enhance students' use of critical lenses for responding to multicultural texts by encouraging students to express their thoughts, think about texts in different ways, and raise questions (Galda \& Beach, 2001). Reflective writing can also allow students to go back to their own writing later and become aware of shifts in their reflections and understanding (Beach et al., 2008; Sumara, 1998). The use of reflective writing and critical lenses can therefore complement the development of students' ability to explain the causes and manifestations of unequal power relations. Research on response to multicultural literature has also shown that reflective writing can encourage students to consider different values, beliefs, and assumptions (e.g., Beach et al., 2008; Lium, 2010). Reflective writing can therefore create what Beach et al. (2008) call dialogic tensions: tensions that occur as students' values or assumptions enter into dialogue with those of other students or people in the text. Providing prompts for writing reflectively about texts that highlight food workers can invite students to grapple with alternative perspectives, recognize how their values shape their interpretations of texts, and begin to understand the factors that shape workers' experiences.

\section{Reflective discussions}

Reflective discussions, whether in the classroom or other settings, in which learners are encouraged to share their initial responses to texts and challenge one another's responses can also create opportunities for grappling with alternative perspectives that may not otherwise arise, especially if learners are reading on their own. It is important to note, however, that discussions that create such dialogic tensions do not necessarily occur on their own, and that guidance and scaffolding by a teacher or facilitator can be crucial for deepening students' meaning-making and promoting critical examination of a text (Athanases, 1998; Galda \& Beach, 2001; Houser, 2001; Long \& Gove, 2003-2004; Singer \& Smith, 2003; Thein, Guise, \& Sloan, 2011). For example, the instructor can nudge students to consider new perspectives (Galda \& Beach, 2001), ask “what-if" hypothetical scenarios that encourage students to take on different views (Beach et al., 2008), use dialogic moves that encourage students to build upon one another's responses (Juzwik, Borsheim-Black, Caughlan, \& Heintz, 2013), and model the use of nonjudgmental language (Thein et al., 2011). Using these strategies, instructors can create an environment where students can build upon, add nuance to, or challenge one another's interpretations of texts and the assumptions, beliefs, or values that underlie those interpretations. Facilitating critical dialogues about multicultural texts that make visible the food workers, then, has the potential to cultivate critical food literacy by encouraging learners to reflect on and interrogate their own beliefs about the food system as well as those of one another.

\section{Production of students' own texts through research}

In preparing learners to help build just and sustainable food systems, they also need to demonstrate the ability to take action. Inviting students to take action in response to texts about food workers, for example, could enable students to expose stereotypes and raise awareness about alternative perspectives regarding food workers or food systems more broadly. This constitutes the actiontaking dimension of critical literacy to transform the world (Luke, 2012; Shor, 1999). Studies suggest that when students respond to texts with social justice themes by conducting research and producing their own texts, they often counter commonly held assumptions and/or challenge norms that perpetuate injustices (Borsheim \& Petrone, 2006; Singer \& Shagoury, 2005/2006). One potentially fruitful way to foster critical food literacy, then, is to give learners the opportunity to produce texts, whether alternate versions of 
existing texts or new texts that highlight their own experiences (or those of their friends or families) of working in the food system.

\section{Using Food Chain Avengers To Help Foster Critical Food Literacy}

To illustrate how the four pedagogical strategies above can be used in conjunction with a multicultural text about food workers to help foster critical food literacy among learners, we use the example of Food Chain Avengers (Dye \& DeLeon, 2014), a comic book published by the Food Chain Workers Alliance to educate youth about food workers. Written by Luis DeLeon, a restaurant worker and member of the Restaurant Opportunities Center of Chicago, ${ }^{4}$ and illustrated by Jerel Dye, artist and social justice advocate, this multicultural text features five characters, each representing one of the five main sectors of the food system: production, processing, distribution, retail, and food service. Based on real experiences of workers, Food Chain Avengers exposes the exploitative nature of corporations in the food system vis-à-vis its workers, communities, and the environment, and also tells the story of struggle to victory of workers uniting to combat injustice and change their workplaces.

One strategy that educators can use to help foster critical food literacy is to encourage learners to read Food Chain Avengers through the critical lenses of race, gender, class, and citizenship status and ask them to consider how the comic book challenges dominant stereotypes based on race, gender, class, and citizenship status, respectively. To support students' inquiries into such questions, they could read horizontal texts, such as reports and videos created by the FCWA over the last few years, that shed light on the historical, political, or social factors that help explain the oppression of food workers.

For example, in 2012, the FCWA published a report entitled The Hands that Feed Us: Challenges and Opportunities for Workers Along the Food Chain. Based on over 600 surveys of food workers and over 40 surveys of employers in the food system, the report

4 The Restaurant Opportunities Center is an organization dedicated to improving wages and working conditions for describes the historical background of corporate consolidation, examines the working conditions of workers across the entire food chain, and illuminates inequities, such as low wages, wage theft, and labor law violations, based on race, gender, and citizenship status (FCWA, 2012a). The FCWA also produced a video series by the same title that features workers across the food chain discussing issues of health and safety and exposes different types of discrimination faced by food workers (FCWA, 2012b; 2013a; 2013b). Another example of a horizontal text that could complement Food Chain Avengers is a report entitled Shelved: How Wages and Working Conditions for California's Food Retail Workers have Declined as the Industry has Thrived. Released in 2014 by the FCWA, the Food Labor Research Center, and Chris Benner, then professor of Community and Regional Development at the University of California, Davis, the report shows that while California's food retail industry has grown consistently in sales and employment, wages have declined and workers face high rates of poverty and hunger. These horizontal texts together provide contextual information that can then help students understand the sources of political, social, or historical structures that oppress food workers.

In addition, to encourage learners to identify and examine their own views and values, educators can provide reflective writing prompts. These prompts could ask them to articulate how the comic made them feel; what connections they can make between the experiences described in the comic and something they have experienced, read, felt, seen, heard about, or learned; or what particular words, phrases, or images in the comic were striking to them. At the same time, educators can complement these self-reflections on the comic by facilitating open discussions that invite students to share their initial responses, build upon or challenge one another's responses, share knowledge, and learn from one another's perspectives.

As learners begin to consider and grapple with multiple perspectives through reflective writing and discussions about Food Chain Avengers and understand the sources of structural oppression that

restaurant workers in the U.S. 
food workers face, they may feel motivated to take action by researching or producing texts of their own. For example, they may want to interview and/or observe family members or friends who are food workers to understand their experiences and perspectives, write a sequel to the comic that explores other issues that food workers face, or develop a version of the comic with an alternative outcome and/or different or additional characters.

While we used the Food Chain Avengers as an illustrative example to show how educators can create space for and potentially cultivate critical food literacy, any number of existing multicultural texts, from books and poems to TED talks and documentaries, could be used as well. It is important to note, however, that further empirical research is needed to determine whether learners demonstrate evidence of critical food literacy through their engagement with Food Chain Avengers or other multicultural texts.

\section{Discussion: Toward Critical Food Literacy}

Multiple types of critical approaches to food systems education programs have begun to emerge and grow in response to the increasing recognition of the need for just, sustainable food systems. Some focus on training underserved youth in multiple aspects of producing, distributing, and marketing food, while others involve learners, including workers, in social movements that seek to build more equitable food systems. In this paper, we have made the case for another critical approach: the use of multicultural texts to foster critical food literacy. In particular, we have argued that engagement with multicultural texts that reveal diverse or conflicting perspectives and make visible food workers who tend to be less visible has the potential to develop critical food literacy.

Exposing learners to these kinds of multicultural texts is crucial, given that learners may not voluntarily seek views that challenge their own perspectives and values. In addition, the processes of responding to and reflecting on multicultural texts may help learners identify and challenge prevailing assumptions that particular behaviors are sustainable and ethical (e.g., eating locally or shopping at farmers markets) or the notions that sustainable food systems can be purchased
(Johnston \& Baumann, 2010) and that citizens can demonstrate civic engagement through consumption and shopping (Jubas, 2012). As Jubas (2012) put it, learners may come to realize that "stores cannot replace ballot boxes and legislatures" (p. 68 ), and that the act of buying locally grown food by itself will not necessarily lead to social, material transformation of existing food systems. We therefore ultimately argue that citizens' engagement with multicultural texts has the potential to prepare and invite them to participate in a "food democracy" (Booth \& Coveney, 2015; Hassanein, 2003, 2008; Lang, 2007) in which citizens grapple with, deliberate across, and work through diverse views and conflicting values to make informed, nuanced decisions that can ultimately contribute to just, sustainable food systems.

The question of whether and how learners develop and demonstrate this kind of critical food literacy is, however, an important and currently underresearched area of inquiry. Additional studies could examine, for example, whether and how learners add nuance to or alter their views regarding food and labor as a result of reflecting on multicultural texts about or by food workers and/or sharing their reactions and perspectives with one another. Furthermore, longitudinal research could illustrate the extent to which particular multicultural texts (or dialogues about such texts) have lasting impacts on students' perspectives and values and/or their interest in seeking alternative perspectives on their own. Another line of inquiry could explore what types of multicultural texts and/or pedagogical strategies facilitate or hinder the development of critical food literacy for a particular group of learners who share similar experiences or demographic characteristics. In addition, comparative research across groups of learners who differ in terms of age, backgrounds, experiences, and/or geographical location could reveal whether and how these characteristics help facilitate or hinder the development of critical food literacy. Studies could also explore whether and how multicultural texts, in conjunction with hands-on learning experiences, such as internships or field trips that expose learners to multiple locations and actors in the food system (including those involved with developing food policies), can help foster critical food literacy. 
All these areas of research can respond to the need for critical scholarship on food systems education, as articulated by scholars (e.g., Flowers \& Swan, 2012; Meek \& Tarlau, 2015), while also offering nuanced insights into the ways in which educators can promote critical food literacy among learners. Ultimately, citizens who demonstrate critical food literacy and engage in democratic discourse about food systems can serve as powerful agents in helping build food systems that are truly just and sustainable for all.

\section{References}

Allen, P., \& Guthman, J. (2006). From "old school” to "farm-to-school": Neoliberalization from the ground up. Agriculture and Human Values, 23(4), 401-415. http://dx.doi.org/10.1007/s10460-0069019-z

Anderson, M. D. (2013). Higher education revisited: Sustainability science and teaching for sustainable food systems. In S. Albrecht, R. Braun, Z. Heuschkel, F. Marí, \& J. Pippig (Eds.), Future of food: State of the art, challenges and options for action (pp. 179188). Munich, Bavaria, Germany: Oekom.

Appleman, D. (2014). Critical encounters in secondary English: Teaching literary theory to adolescents. New York: Teachers College Press.

Athanases, S. Z. (1998). Diverse learners, diverse texts: Exploring identity and difference through literary encounters. Journal of Literacy Research, 30(2), 273296.

http://dx.doi.org/10.1080/10862969809547999

Bagdonis, J. M., Hinrichs, C. C., \& Schafft, K. A. (2009). The emergence and framing of farm-to-school initiatives: Civic engagement, health and local agriculture. Agriculture and Human Values, 26(1), 107-119. http://dx.doi.org/10.1007/s10460-0089173-6

Barlett, P. F. (2011). Campus sustainable food projects: Critique and engagement. American Anthropologist, 113(1), 101-115. http://dx.doi.org/10.1111/j.15481433.2010.01309.x

Beach, R., Thein, A. H., \& Parks, D. L. (2008). High school students' competing social worlds: Negotiating identities and allegiances in response to multicultural literature. New York: Taylor \& Francis.

Blair, D. (2009). The child in the garden: An evaluative review of the benefits of school gardening. The
Journal of Environmental Education, 40(2), 15-38. http://dx.doi.org/10.3200/JOEE.40.2.15-38

Booth, S., \& Coveney, J. (2015). Food democracy: From consumer to food citizen. Singapore: Springer. http://dx.doi.org/10.1007/978-981-287-423-8

Borsheim, C., \& Petrone, R. (2006). Teaching the research paper for local action. The English Journal, 95(4), 78-83. http://dx.doi.org/10.2307/30047094

Bredo, E., \& Feinberg, W. (1982). Knowledge and values in social and educational research. Philadelphia: Temple University Press.

Burdick, J. M. (2014). "Good for you and good to you": The importance of emphasizing race when radicalizing students around the food movement. Radical Teacher, 98, 22-30. http://dx.doi.org/10.5195/rt.2014.72

Burns, H. (2011). Teaching for transformation: (Re)Designing sustainability courses based on ecological principles. Journal of Sustainability Education, 2. Retrieved from http://pdxscholar. library.pdx.edu/cgi/viewcontent.coi? article $=1025 \&$ context $=$ elp_fac

Caldwell, M. L. (2014). Playing with food (studies): Rethinking experience-based learning in American food studies teaching. In R. D. Mitchell (Ed.), Food design on the edge: Proceedings of the International Food Design Conference and Studio (pp. 37-41). Dunedin, New Zealand: Otago Polytechnic.

Chez Panisse Foundation. (2008). Principles of an edible education: A vision for school lunch. Retrieved from https://edibleschoolyard.org/sites/default/files/ Principle $\% 20$ of $\% 20$ an $\% 20$ Edible $\% 20$ Education A $\% 20$ Vision $\% 20$ for $\% 20$ School $\% 20$ Lunch.pdf

Coveney, J., Begley, A., \& Gallegos, D. (2012). 'Savoir Fare': Are cooking skills a new morality? Australian Journal of Adult Learning, 52(3), 617-642.

Cullen, T., Hatch, J., Martin, W., Higgins, J. W., \& Sheppard, R. (2015). Food literacy: Definition and framework for action. Canadian Journal of Dietetic Practice and Research, 76(3), 140-145. http://dx.doi.org/10.3148/cjdpr-2015-010

Dewey, J. (1938). Experience and education. New York: Touchstone Books.

Dixon, B. A. (2015). Rewriting the call to charity: From food shelf volunteer to food justice advocate. Journal of Agriculture, Food Systems, and Community Development, 5(2), 71-79. http://dx.doi.org/10.5304/jafscd.2015.052.010 
Dye, J., \& DeLeon, L. (2014). Food chain avengers: A food justice \& worker justice comic book. Los Angeles: Food Chain Workers Alliance.

Feenstra, G., \& Ohmart, J. (2012). The evolution of the School Food and Farm to School Movement in the United States: Connecting childhood health, farms, and communities. Childhood Obesity, 8(4), 280-289. http://online.liebertpub.com/doi/abs/10.1089/ chi. 2012.0023

Flowers, R., \& Swan, E. (2011). 'Eating at us': Representations of knowledge in the activist documentary film Food, Inc. Studies in the Education of Adults, 43(2), 234-250.

Flowers, R., \& Swan, E. (2012). Introduction: Why food? Why pedagogy? Why adult education? Australian Journal of Adult Learning, 52(3), 419-433. http://www.ajal.net.au/introduction-why-foodwhy-pedagogy-why-adult-education/

Food Chain Workers Alliance. (2012a). The hands that feed us: Opportunities and challenges for workers along the food chain. Retrieved from http://foodchainworkers. org/wp-content/uploads/2012/06/Hands-ThatFeed-Us-Report.pdf

Food Chain Workers Alliance. (2012b, November 23). The hands that feed us, part I [Video file]. Retrieved from https://www.youtube.com/watch?v= IsRyTmBc3NA

Food Chain Workers Alliance. (2013a, Feburary 4). The hands that feed us, part II: Low wages \& long hours [Video file]. Retrieved from https://www.you tube.com/watch? $\mathrm{v}=$ ztRS6HCY7oc

Food Chain Workers Alliance. (2013b, April 1). The hands that feed us, part III: Discrimination [Video file]. Retrieved from https://www.youtube.com/watch?v=PY5irx67kt4

Forssell, S., \& Lankoski, L. (2015). The sustainability promise of alternative food networks: An examination through "alternative" characteristics. Agriculture and Human V alues, 32(1), 63-75. http://dx.doi.org/10.1007/s10460-014-9516-4

Freedman, D. A. (2011). Embodying food studies: Unpacking the ways we become what we eat. In M. J. Casper \& P. Currah (Eds.), Corpus: $A n$ interdisciplinary reader on bodies and knowledge (pp. 8193). Basingstoke, UK: Palgrave Macmillan.

Freire, P. (1985). Reading the world and reading the word: An interview with Paulo Freire. Language Arts, 62(1), 15-21.
Galda, L., \& Beach, R. (2001). Response to literature as a cultural activity. Reading Research Quarterly, 36(1), 64-73. http://dx.doi.org/10.1598/RRQ.36.1.4

Galt, R. E., Parr, D., Van Soelen Kim, J., Beckett, J., Lickter, M., \& Ballard, H. (2013). Transformative food systems education in a land-grant college of agriculture: The importance of learner-centered inquiries. Agriculture and Human V alues, 30(1), 129_ 142. http:/ /dx.doi.org/10.1007/s10460-012-9384-8

Gayeton, D. (2014). Local: The new face of food and farming in America. New York: Harper Design.

Gellis, M. (2002). Master questions and the teaching of literature. In J. Holden \& J. S. Schmit (Eds.), Inquiry and the literary text: Constructing discussions in the English classroom (pp. 15-35). Urbana, Illinois: National Council of Teachers of English.

Geuss, R. (1981). The idea of a critical theory: Habermas and the Frankfurt school. Cambridge, UK: Cambridge University Press.

Goldstein, S. (2014). Advancing youth education on food and food systems to increase food literacy (Master's thesis). Retrieved from http://hdl.handle.net/10315/30215

Goodman, D., \& DuPuis, E. M. (2002). Knowing food and growing food: Beyond the productionconsumption debate in the sociology of agriculture. Sociologia Ruralis, 42(1), 5-22. http://dx.doi.org/10.1111/1467-9523.00199

Gray, M. (2013). Labor and the locavore: The making of a comprehensive food ethic. Berkeley: University of California Press.

Guthman, J. (2008). Bringing good food to others: Investigating the subjects of alternative food practice. Cultural Geographies, 15(4), 431-447. http://dx.doi.org/10.1177/1474474008094315

Hassanein, N. (2003). Practicing food democracy: A pragmatic politics of transformation. Journal of Rural Studies, 19(1), 77-86.

http://dx.doi.org/10.1016/S0743-0167(02)00041-4

Hassanein, N. (2008). Locating food democracy: Theoretical and practical ingredients. Journal of Hunger \& Environmental Nutrition, 3(2-3), 286-308. http://dx.doi.org/10.1080/19320240802244215

Hilimire, K., Gillon, S., McLaughlin, B. C., Dowd-Uribe, B., \& Monsen, K. L. (2014). Food for thought: Developing curricula for sustainable food systems education programs. Agroecology and Sustainable Food Systems, 38(6), 722-743. http://dx.doi.org/10.1080/21683565.2014.881456 
Holloway, L., Kneafsey, M., Venn, L., Cox, R., Dowler, E., \& Tuomainen, H. (2007). Possible food economies: A methodological framework for exploring food production-consumption relationships. Sociologia Ruralis, 47(1), 1-19. http://dx.doi.org/10.1111/j.1467-9523.2007. 00427.x

Houser, N. O. (2001). Literature as art, literature as text: Exploring the power and possibility of a critical, literacy-based approach to citizenship education. Equity \& Excellence in Education, 34(2), 62-74. http://dx.doi.org/10.1080/1066568010340209

Jayaraman, S. (2013). Behind the kitchen door. Ithaca, New York: Cornell University Press.

Johnston, J., \& Baumann, S. (2010). Foodies: Democracy and distinction in the gourmet foodscape. New York: Routledge.

Jordan, N., Grossman, J., Lawrence, P., Harmon, A. H., Dyer, W., Maxwell, B.,...Tzenis, C. (2014). New curricula for undergraduate food-systems education: A sustainable agriculture education perspective. NACTA Journal, 58(4), 302-310.

Jubas, K. (2012). Critically minded shopping as a process of adult learning and civic engagement. New Directions for Adult and Continuing Education, 2012(135), 61-69.

http://dx.doi.org/10.1002/ace.20027

Julier, A., \& Gillespie, G. W., Jr. (2012). Encountering food systems: A conversation about thinking, teaching and social change. Food, Culture \& Society, 15(3), 359-373. http://dx.doi.org/10.2752/17517 4412X13276629245768

Juzwik, M. M., Borsheim-Black, C., Caughlan, S., \& Heintz, A. (2013). Inspiring dialogue: Talking to learn in the English classroom. New York: Teachers College Press.

Kimura, A. H. (2011). Food education as food literacy: Privatized and gendered food knowledge in contemporary Japan. Agriculture and Human Values, 28(4), 465-482. http://dx.doi.org/10.1007/s10460010-9286-6

Kolb, D. A. (2014). Experiential learning: Experience as the source of learning and development ( $2^{\text {nd }} \mathrm{ed}$.). Upper Saddle River, New Jersey: Pearson Education.

Lang, T. (2007). Food security or food democracy? Pesticides News, 78, 12-16.

Lewis, C., Pyscher, T., \& Stutelberg, E. (2015). A critical sociocultural approach to English education. In J. Brass \& A. Webb (Eds.), Reclaiming English language arts methods courses: Critical issues and challenges for teacher educators in top-down times (pp. 22-39). New York: Routledge.

Lewison, M., Flint, A. S., \& Van Sluys, K. (2002). Taking on critical literacy: The journey of newcomers and novices. Language Arts, 79(5), 382-392.

Lium, K. L. (2010). Exploring aesthetic reading, multicultural literature and social consciousness with 11 - and 12-year old resistant readers (Doctoral dissertation). Retrieved from ProQuest Dissertations and Theses. (Accession Order No. AAT 3422227.)

Long, T. W., \& Gove, M. K. (2003-2004). How engagement strategies and literature circles promote critical response in a fourth-grade urban classroom. The Reading Teacher, 57(4), 350-361. http://www.jstor.org/stable/20205370

Luke, A. (2012). Critical literacy: Foundational notes. Theory Into Practice, 51(1), 4-11. http://dx.doi.org/10.1080/00405841.2012.636324

Meek, D., \& Tarlau, R. (2015). Critical food systems education and the question of race. Journal of Agriculture, Food Systems, and Community Development, 5(4), 131-135. http://dx.doi.org/10.5304/jafscd.2015.054.021

Paddock, J. (2015). Positioning food cultures: 'Alternative' food as distinctive consumer practice. Advance online publication. Sociology, 1-17. http://dx.doi.org/10.1177/0038038515585474

Parr, D. M., \& Trexler, C. J. (2011). Students' experiential learning and use of student farms in sustainable agriculture education. Journal of Natural Resources \& Life Sciences Education, 40(1), 172-180. http://dx.doi.org/10.4195/jnrlse.2009.0047u

Pudup, M. B. (2008). It takes a garden: Cultivating citizen-subjects in organized garden projects. Geoforum, 39(3), 1228-1240. http://dx.doi.org/10.1016/j.geoforum.2007.06.012

Rosenblatt, L. M. (1982). The literary transaction: Evocation and response. Theory into Practice, 21(4), 268-277. http://dx.doi.org/10.1080/00405848209543018

Rosenblatt, L. M. (1994). The reader, the text, the poem: The transactional theory of the literary work ( $2^{\text {nd }} \mathrm{ed}$.). Carbondale: Southern Illinois University Press.

Rosenblatt, L. M. (2003). Literary theory. In J. Flood, D. Lapp, J. R. Squire, \& J. M. Jensen (Eds.), Handbook of research on teaching the English language arts, $2^{\text {nd }} \mathrm{ed}$. (pp. 67-73). Mahwah, New Jersey: Lawrence Erlbaum. 
Sayre, L., \& Clark, S. (Eds.). (2011). Fields of learning: The student farm movement in North America. Lexington: University Press of Kentucky.

Shor, I. (1999). What is critical literacy? In I. Shor \& C. Pari (Eds.), Critical literacy in action: Writing words, changing worlds (pp. 1-29). Portsmouth, New Hampshire: Heinemann Press.

Singer, J., \& Shagoury, R. (2005/2006). Stirring up justice: Adolescents reading, writing, and changing the world. Journal of Adolescent \& Adult Literacy, 49(4), 318-339.

http://dx.doi.org/10.1598/JAAL.49.4.5

Singer, J. Y., \& Smith, S. A. (2003). The potential of multicultural literature: Changing understanding of self and others. Multicultural Perspectives, 5(2), 17-23. http://dx.doi.org/10.1207/S15327892MCP0502 4

Sumara, D. J. (1998). Fictionalizing acts: Reading and the making of identity. Theory Into Practice, 37(3), 203-210. http://dx.doi.org/10.1080/00405849809543806

Sumner, J. (2013). Food literacy and adult education: Learning to read the world by eating. The Canadian Journal for the Study of Adult Education, 25(2), 79-91.

Swan, E., \& Flowers, R. (2015). Clearing up the table: Food pedagogies and environmental educationContributions, challenges and future agendas. Australian Journal of Enviromental Education, 31(1), 146-164. http://dx.doi.org/10.1017/aee.2015.27

Thein, A. H., Guise, M., \& Sloan, D. L. (2011). Problematizing literature circles as forums for discussion of multicultural and political texts. Journal of Adolescent \& Adult Literacy, 55(1), 15-24. http://onlinelibrary.wiley.com/doi/10.1598/JAAL. $\underline{55.1 .2 / \text { abstract }}$
Vidgen, H. A., \& Gallegos, D. (2014). Defining food literacy and its components. Appetite, 76, 50-59. http://dx.doi.org/10.1016/j.appet.2014.01.010

Wals, A. E. J., \& Dillon, J. (2013). Conventional and emerging learning theories: Implications and choices of educational researchers with a planetary consciousness. In R. B. Stevenson, M. Brody, J. Dillon, \& A. E. J. Wals (Eds.), International handbook of research on environmental education (pp. 253-261). New York: Routledge. http://dx.doi.org/10.4324/9780203813331.ch26

Walter, P. (2012). Educational alternatives in food production, knowledge and consumption: The public pedagogies of Growing Power and Tsyunhehkw^. Australian Journal of Adult Learning, 52(3), 573-594.

Wever, C. (2015). Cultivating critical learning: Critical food pedagogy in FoodShare's School Grown Program (Master's thesis). Retrieved from http://fes.yorku.ca/files/outstanding-papers/ Cassie Wever FINAL MRP.pdf

Williams, D. R., \& Dixon, P. S. (2013). Impact of garden-based learning on academic outcomes in school: Synthesis of research between 1990 and 2010. Review of Educational Research, 83(2), 211-235. http://dx.doi.org/10.3102/0034654313475824

Winslow, D. (2012). Food for thought: Sustainability, community-engaged teaching and research, and critical food literacy (Doctoral dissertation). Retrieved from ProQuest Dissertations and Theses. (Accession Order No. AAT 3517897.) 